\title{
In situ FT-IR spectroscopic investigation of gold supported on tungstated zirconia as catalyst for CO-SCR of $\mathrm{NO}_{x}$
}

\author{
M. Kantcheva*, M. Milanova, S. Mametsheripov \\ Department of Chemistry, Bilkent University, 06800 Ankara, Turkey
}

\section{A R T I C L E I N F O}

\section{Article history:}

Received 27 February 2012

Accepted 23 March 2012

Available online xxx

\section{Keywords:}

$\mathrm{Au} / \mathrm{ZrO}_{2}-\mathrm{WO}_{x}$

In situ FT-IR spectroscopy

$\mathrm{NO}_{x}+\mathrm{CO}$ surface reaction

CO-SCR of $\mathrm{NO}_{x}$

\begin{abstract}
A B S T R A C T
The possibility for application of gold supported on tungstated zirconia as catalyst in the selective catalytic reduction of $\mathrm{NO}_{x}$ with $\mathrm{CO}$ (CO-SCR) has been investigated by means of in situ FT-IR spectroscopy. Tungstated zirconia containing $18 \mathrm{wt} \%$ of $\mathrm{WO}_{3}$ was prepared by co-precipitation. Gold was deposited on zirconia and tungstated zirconia by cationic adsorption using $\left[\mathrm{Au}(\mathrm{en})_{2}\right] \mathrm{Cl}_{3}$ as a precursor (en = ethylenediamine). The FT-IR spectra obtained during the interaction of CO with $\mathrm{NO}_{x}$ species adsorbed on the $\mathrm{Au} / \mathrm{ZrO}_{2}-\mathrm{WO}_{x}$ and $\mathrm{Au} / \mathrm{ZrO}_{2}$ samples revealed the formation of surface isocyanates attached to the gold particles. The generation of Au-NCO species occurred at low temperature $\left(25-50{ }^{\circ} \mathrm{C}\right)$. The $\mathrm{W}$-containing sample was characterized by higher activity in the ad- $\mathrm{NO}_{x}+\mathrm{CO}$ reaction than the $\mathrm{W}$ free one. It is shown that the nitrate species or adsorbed $\mathrm{NO}_{2}$ are essential for the generation of surface isocyanates and the oxidation of NO by oxygen is an important step. The obtained results suggest that $\mathrm{Au}$ catalysts supported on tungstated zirconia might be of interest for the selective reduction of $\mathrm{NO}_{x}$ with $\mathrm{CO}$ at low temperatures.
\end{abstract}

(c) 2012 Elsevier B.V. All rights reserved.

\section{Introduction}

The selective reduction of $\mathrm{NO}_{x}$ in the presence of oxygen is a very promising technology to control the emissions from diesel and lean-burn engines. Reduction of $\mathrm{NO}_{x}$ using either the residual hydrocarbons or on-board fuel would be the most ideal technology. However, the traditional materials developed for the selective reduction of $\mathrm{NO}_{x}$ with hydrocarbons (HC-SCR) do not show sufficient activities under the conditions of lean exhaust especially at low temperatures $\left(<150-250^{\circ} \mathrm{C}\right)$ [1-4]. One of the typical reductant present in the car exhaust is CO. Recently $\mathrm{Ir} / \mathrm{SiO} \mathrm{O}_{2}, \mathrm{Ir} / \mathrm{WO}_{3}$ and $\mathrm{Ir} / \mathrm{WO}_{3} / \mathrm{SiO}_{2}$ catalysts have been reported to be highly active in the selective reduction of NO with $\mathrm{CO}(\mathrm{CO}-\mathrm{SCR})$ [5-11]. However, these catalysts show activity in the $260-400{ }^{\circ} \mathrm{C}$ temperature window. Supported gold catalysts are known to be highly active in variety of reactions at low temperatures [12,13]. In the present study, we report the results of FT-IR spectroscopic characterization of gold catalyst supported on tungstated zirconia. In order to evaluate the potential of a new material as a catalyst in a desired process, it is important to investigate the interaction of the reactants with the surface. For this purpose we studied the adsorption of $\mathrm{CO}$ and its co-adsorption with oxygen and NO over Au-promoted and Au-free tungstated zirconia.

\footnotetext{
* Corresponding author.

E-mail address: margi@fen.bilkent.edu.tr (M. Kantcheva).
}

\section{Experimental}

\subsection{Sample preparation}

The sample preparation is described in detail elsewhere [14]. In brief, tungstated zirconia was synthesized by co-precipitation [15] with nominal content of $18 \mathrm{wt} \%$ of $\mathrm{WO}_{3}$. Gold was deposited on tungstated zirconia by cation adsorption for $2 \mathrm{~h}$ from aqueous solution of $\left[\mathrm{Au}(\mathrm{en})_{2}\right]^{3+}$ complex at $\mathrm{pH}=9.6$ and room temperature. After drying of the washed solid at $80^{\circ} \mathrm{C}$ for $48 \mathrm{~h}$, the sample was calcined for $1 \mathrm{~h}$ at $400^{\circ} \mathrm{C}$. The cationic gold precursor was prepared following the procedure of Block and Bailar [16]. The sample was labeled as $\mathrm{Au} / 18 \mathrm{WZ}-\mathrm{CP}$.

In order to study the effect of tungsten, gold was deposited on tetragonal zirconia also by cation adsorption of $\left[\mathrm{Au}(\mathrm{en})_{2}\right]^{3+} \mathrm{com}-$ plex using the same conditions applied to the $\mathrm{W}$-containing sample.

\subsection{Sample characterization}

The samples were characterized by XRD, DR-UV-vis spectroscopy, BET measurements and chemical analysis, and the results were reported earlier [14].

The FT-IR spectra were recorded using a Bomem Hartman \& Braun MB-102 model FT-IR spectrometer with a liquid-nitrogen cooled MCT detector at a resolution of $4 \mathrm{~cm}^{-1}$ (100 scans). The self-supporting discs $\left(\sim 0.01 \mathrm{~g} / \mathrm{cm}^{2}\right)$ were activated in the IR cell by heating for $1 \mathrm{~h}$ in a vacuum at $400^{\circ} \mathrm{C}$, and in oxygen (100 Torr, 
Table 1

Physico-chemical characterization of the investigated samples.

\begin{tabular}{|c|c|c|c|c|}
\hline Sample & $S_{\text {BET }}\left(\mathrm{m}^{2} / \mathrm{g}\right)$ & $\mathrm{WO}_{3}(\mathrm{wt} \%)$ & Au loading (wt\%) & $\begin{array}{l}\text { Average Au particle } \\
\text { size }(\mathrm{nm})\end{array}$ \\
\hline $\mathrm{ZrO}_{2}$ & 152 & - & & \\
\hline $\mathrm{Au} / \mathrm{ZrO}_{2}$ & 143 & - & $1.43 \pm 0.03$ & 8 \\
\hline 18WZ-CP & 116 & 18.0 & - & \\
\hline $\mathrm{Au} / 18 \mathrm{WZ}-\mathrm{CP}$ & 118 & 17.6 & $2.27 \pm 0.01$ & 10 \\
\hline
\end{tabular}

passed through a trap cooled in liquid nitrogen) at the same temperature, followed by evacuation for $1 \mathrm{~h}$ at $400^{\circ} \mathrm{C}$. The spectra of adsorbed gases were obtained by subtracting the spectra of the activated sample from the spectra recorded. The sample spectra were also gas-phase corrected.

\section{Results and discussion}

\subsection{Structural characterization}

Table 1 summarizes the chemical composition and BET surface areas of the samples. The results of the chemical analysis [14] show that the gold uptake on tungstated zirconia is higher than that on zirconia. It is well known that tungstated zirconia contains acidic protons $[15,17-21]$ which in basic medium can undergo deprotonation. This can lead to the formation of greater number of $\mathrm{M}-\mathrm{O}^{-}$ anchoring sites $(\mathrm{M}=\mathrm{W}$ and $\mathrm{Zr})$ for the $\left[\mathrm{Au}(\mathrm{en})_{2}\right]^{3+}$ complex resulting in higher gold uptake.

According to the XRD data [14] the materials have the structure of tetragonal zirconia. The average size of gold particles (Table 1 ) is calculated by using Scherrer equation and the main gold diffraction line of $2 \theta=38.2^{\circ}$. The DR-UV-vis spectra of gold containing samples [14] exhibit broad absorption with maximum at $550-590 \mathrm{~nm}$ characteristic of the plasmonic oscillation mode of nanosized gold particles [22-24].

\subsection{Adsorption of $\mathrm{CO}$ at room temperature}

The analysis of the FT-IR spectra of CO adsorbed at room temperature on the samples can be very useful to obtain qualitative information on the nature of supported gold species. Fig. 1 displays the FT-IR spectra in the carbonyl region of CO (10 Torr) adsorbed on the activated Au-containing samples. The absorption at $2194-2198 \mathrm{~cm}^{-1}$ is assigned to $\mathrm{CO}$ adsorbed on $\mathrm{Zr}^{4+}$ surface sites $[18,21,23,25-27]$. The high-frequency shift exhibited in the $\mathrm{WO}_{x}$-containing material is associated with the increased acidity of the coordinative unsaturated $\mathrm{Zr}^{4+}$ sites caused by the electronwithdrawing $\mathrm{WO}_{x}$ groups $[18,21]$. The band corresponding to the $\mathrm{Zr}^{4+}-\mathrm{CO}$ species and the composed band with maximum at $2113-2116 \mathrm{~cm}^{-1}$ are removed upon dynamic evacuation at room temperature. According to data from the literature [23,25-39], the absorption with maximum at $2113-2116 \mathrm{~cm}^{-1}$ is assigned to CO adsorbed on small three-dimensional gold clusters, whereas the shoulder at $2125-2130 \mathrm{~cm}^{-1}$ could be attributed to $\mathrm{Au}^{\delta+}-\mathrm{CO}$ species. Formation of positively polarized gold is assumed to be caused by the presence of adsorbed oxygen on the gold particles or their interaction with the support [23,24,26,28,31,32,35-37]. Hadjiivanov and coworkers [36,37] proposed that the absorption in the $2155-2130 \mathrm{~cm}^{-1}$ region could be attributed also to $\mathrm{Au}^{+}-\mathrm{CO}$ species in which the $\mathrm{Au}^{+}$cation resides on the metallic gold particles. It should be noted that the last activation step of the samples consisted of evacuation at $400^{\circ} \mathrm{C}$ and adsorbed oxygen cannot be expected under these conditions. Moreover, after the reduction of the samples at $400{ }^{\circ} \mathrm{C}$ with $\mathrm{CO}$, the absorption at $2125-2130 \mathrm{~cm}^{-1}$ is still present in the spectra of $\mathrm{CO}$ adsorbed at room temperature. Therefore, it could be proposed that the feature at $2125-2130 \mathrm{~cm}^{-1}$ could be associated with the presence of more defective gold sites located most likely at the interface. It cannot be excluded that the absorption at $2125-2130 \mathrm{~cm}^{-1}$ is associated with the presence of larger Au particles. This proposition could be supported by the fact that $\mathrm{CO}$ adsorbed on small gold particles is characterized by $v(\mathrm{CO})$ mode at lower wavenumbers and the $v(\mathrm{CO})$ stretching vibration is blue-shifted as the particle size increases [40]. Recently, absorption band at $2130-2140 \mathrm{~cm}^{-1}$ observed upon CO adsorption on $\mathrm{Au} / \mathrm{Nb}_{2} \mathrm{O}_{5}$ has been attributed to $\mathrm{CO}$ coordinated to larger gold nanoparticles [41].

\subsection{In situ FT-IR spectroscopic investigation of the $\mathrm{NO}+\mathrm{O}_{2}+\mathrm{CO}$ reaction}

\subsection{1. $\mathrm{NO}+\mathrm{O}_{2}$ surface reaction}

In general, the mechanism of $\mathrm{SCR}$ of $\mathrm{NO}_{x}$ on various oxide catalysts involves the interaction of strongly adsorbed $\mathrm{NO}_{x}{ }^{-}$species $(x$ is 2 or 3 ) with the reducer [2,42-46]. Therefore we studied the thermal stability of $\mathrm{NO}_{x}$ species adsorbed on the surface of the $18 \mathrm{WZ}-\mathrm{CP}$ and $\mathrm{Au} / 18 \mathrm{WZ}-\mathrm{CP}$ samples.

$\mathrm{NO}_{x}$ species on the surface of the $\mathrm{Au} / 18 \mathrm{WZ}-\mathrm{CP}$ sample were created by adsorption of a (10 Torr $\mathrm{NO}+25 \mathrm{Torr} \mathrm{O}_{2}$ ) mixture at room temperature followed by evacuation for $20 \mathrm{~min}$ at the same temperature (Fig. 2A, spectrum (a)). The absorption bands in the $1700-1000 \mathrm{~cm}^{-1}$ range are typical of surface nitrates observed on tungstated zirconia [45-47] and are identified as monodentate $\left(1582\right.$ and $1275 \mathrm{~cm}^{-1}$ ) and bidentate (1629 and $1219 \mathrm{~cm}^{-1}$ ) $\mathrm{NO}_{3}{ }^{-}$species. The broad absorption centered at $2140 \mathrm{~cm}^{-1}$ is

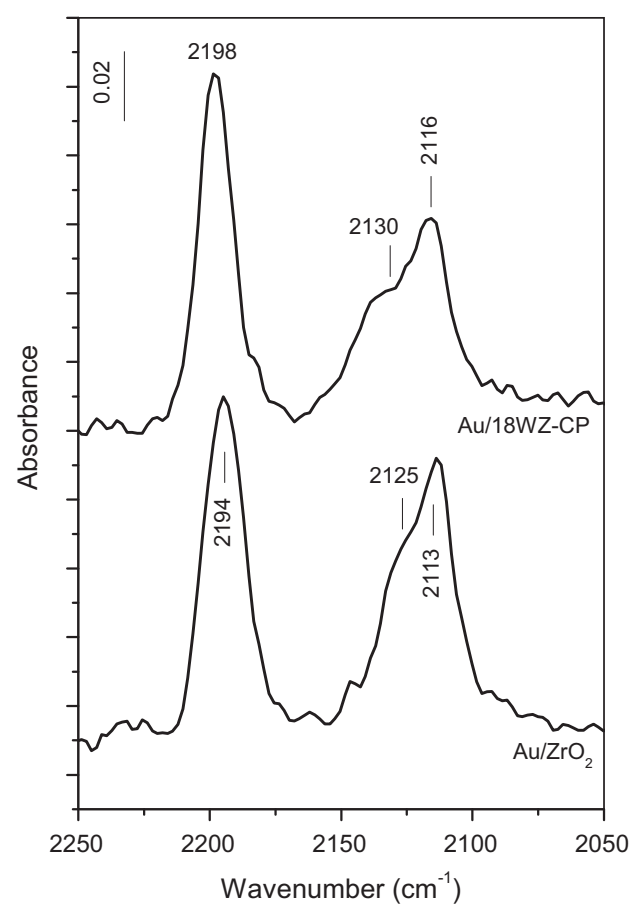

Fig. 1. FT-IR spectra of CO (10 Torr) adsorbed at room temperature on the samples studied. 


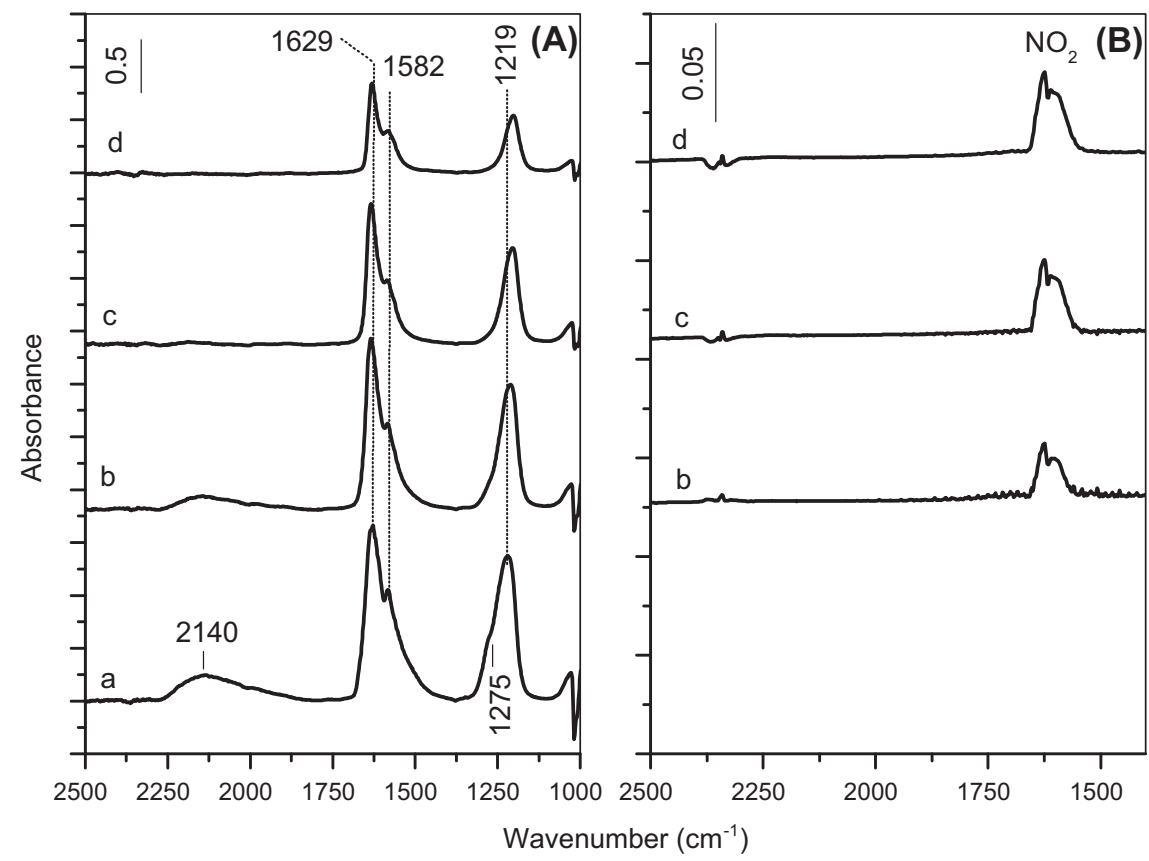

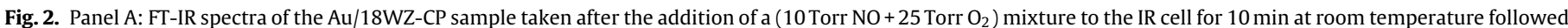

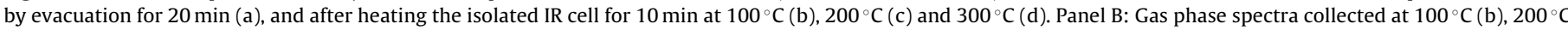
(c) and $300^{\circ} \mathrm{C}(\mathrm{d})$.

characteristic of $\mathrm{NO}^{+}$species [45-47]. Heating the isolated IR cell in the temperature range $100-300^{\circ} \mathrm{C}$, leads to gradual decrease in the intensities of the nitrate bands. The spectra of the gas phase (Fig. 2B) show that the major product of decomposition of the surface nitrates is $\mathrm{NO}_{2}$. The Au-free $18 \mathrm{WZ}-\mathrm{CP}$ sample contains analogous type of adsorbed $\mathrm{NO}_{x}$ species which were generated by the same way as described above (the spectra are not shown). However, the surface nitrates on the Au-containing sample display higher thermal stability.

There are reports in the literature [35,37], showing that a mixture of $\mathrm{NO}+\mathrm{O}_{2}$ can cause oxidation of supported metallic gold particles to cationic gold species and this process can occur at room temperature. In order to find the effect of co-adsorption of $\mathrm{NO}+\mathrm{O}_{2}$ mixture on the oxidation state of gold in the Au/18WZ-CP sample, we investigated the adsorption of $\mathrm{CO}$ on the catalyst containing pre-adsorbed $\mathrm{NO}_{x}$ species. It is well known that the spectral features of adsorbed $\mathrm{CO}$ can provide information about the oxidation state of the adsorption site [34]. Surface nitrate species (absorption bands between 1700 and $1000 \mathrm{~cm}^{-1}$ ) were generated by bringing in contact the $\mathrm{Au} / 18 \mathrm{WZ}-\mathrm{CP}$ sample with a mixture of 10 Torr of $\mathrm{NO}$ and 25 Torr of $\mathrm{O}_{2}$ for $10 \mathrm{~min}$ at room temperature followed by evacuation at the same temperature for $20 \mathrm{~min}$ (Fig. 3, spectrum (a)). To the sample treated in this way, 10 Torr of CO were added. The spectrum detected at room temperature after 5 min contains a strong band with maximum at $2185 \mathrm{~cm}^{-1}$ (Fig. 3, spectrum (b)). The intensity of this signal increases significantly after $10 \mathrm{~min}$ of contact with the CO (Fig. 3, spectrum (c)). Weak absorption at $2130 \mathrm{~cm}^{-1}$ is observed as well whose intensity increases in parallel with the main band at $2185 \mathrm{~cm}^{-1}$. The latter signal falls in the range of reported $v(\mathrm{CO})$ stretching vibrations of $\mathrm{Au}^{+}-\mathrm{CO}$ species $\left(2197-2160 \mathrm{~cm}^{-1}\right.$ [31-37]). However, the increase in the intensity of the band at $2185 \mathrm{~cm}^{-1}$ during the contact with CO contradicts the observed instability of the $\mathrm{Au}^{+}-\mathrm{CO}$ species in $\mathrm{CO}$ atmosphere [31-33,35] due to reduction of $\mathrm{Au}^{+}$adsorption sites by $\mathrm{CO}$.

In order to ensure more efficient oxidation of gold, the catalyst pellet was treated with a ( 10 Torr $\mathrm{NO}+25$ Torr $\left.\mathrm{O}_{2}\right)$ mixture at $300^{\circ} \mathrm{C}$ for $30 \mathrm{~min}$. Then the temperature was lowered to $200^{\circ} \mathrm{C}$ and the gas mixture was removed from the IR cell upon dynamic evacuation while cooling to room temperature. Subsequent adsorption of $\mathrm{CO}$ (10 Torr) at room temperature results in the formation of weak absorption bands at 2190 and $2165 \mathrm{~cm}^{-1}$ (Fig. 4, spectrum (a)). The spectrum in the nitrate region (not shown) displays the same set of nitrate bands as shown in Fig. 2A, although with weaker intensity. The band at $2190 \mathrm{~cm}^{-1}$ resists the evacuation at room temperature (Fig. 4, spectrum (b)) and disappears upon outgassing at $100^{\circ} \mathrm{C}$ (Fig. 4, spectrum (d)). The observed behavior of the absorption at $2190 \mathrm{~cm}^{-1}$ is typical of $\mathrm{Au}^{+}-\mathrm{CO}$ species [34]. The $\mathrm{CO}$ adsorbed on $\mathrm{Au}^{+}$sites is stabilized by the synergism between the $\sigma$-dative and $\pi$ back-bonding components of the $\mathrm{Au}^{+}-\mathrm{CO}$ bond [34-37] and the carbonyl complex can be destroyed at temperature higher than $25^{\circ} \mathrm{C}$. The absorption at $2165 \mathrm{~cm}^{-1}$ disappears upon evacuation at room temperature (Fig. 4, spectrum (b)) and could be attributed to $\mathrm{Au}^{\delta+}-\mathrm{CO}$ species or $\mathrm{CO}$ adsorbed on large

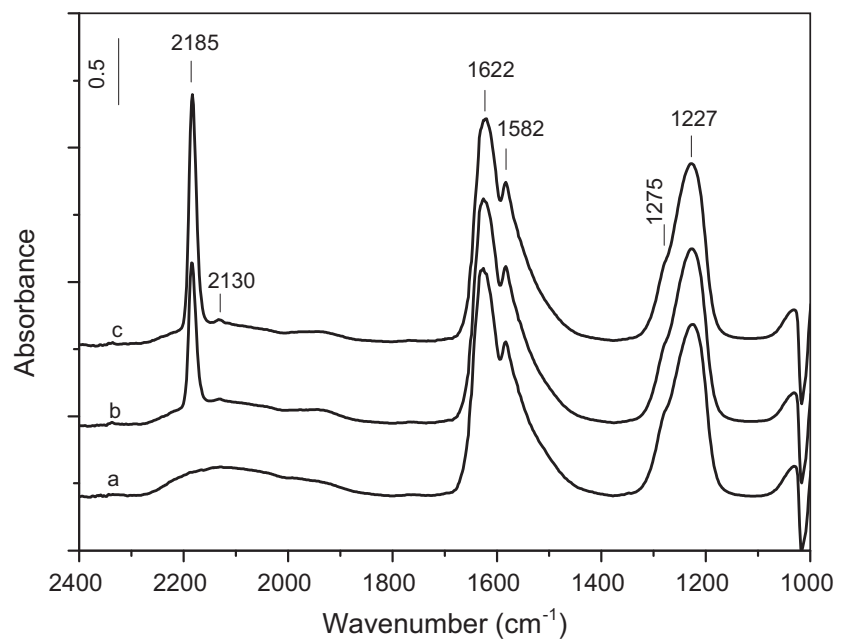

Fig. 3. FT-IR spectra of the $\mathrm{Au} / 18 \mathrm{WZ}-\mathrm{CP}$ catalyst collected after the adsorption of a (10 Torr $\mathrm{NO}+25$ Torr $\mathrm{O}_{2}$ ) mixture for $10 \mathrm{~min}$ at room temperature followed by evacuation for $20 \mathrm{~min}$ at room temperature (a) and adsorption of 10 Torr $\mathrm{CO}$ at room temperature for $5 \mathrm{~min}$ (b) and $10 \mathrm{~min}(\mathrm{c})$. 


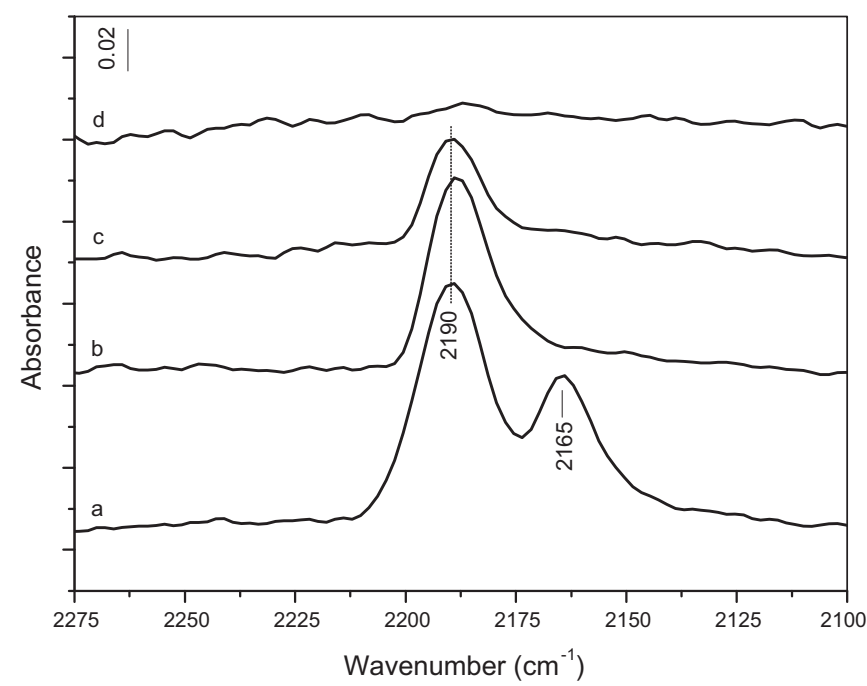

Fig. 4. FT-IR spectra of the Au/18WZ-CP sample collected after the adsorption of a $\left(10\right.$ Torr $\mathrm{NO}+25$ Torr $\left.\mathrm{O}_{2}\right)$ mixture for $30 \mathrm{~min}$ at $300^{\circ} \mathrm{C}$ followed by dynamic evacuation from $200^{\circ} \mathrm{C}$ to room temperature and subsequent adsorption of 10 Torr of $\mathrm{CO}$ for $10 \mathrm{~min}$ (a), evacuation for $15 \mathrm{~min}$ at room temperature (b), $50^{\circ} \mathrm{C}$ (c) and $100^{\circ} \mathrm{C}$ (d).

gold particles. This band is found at higher frequency than the corresponding band observed on the activated $\mathrm{Au} / 18 \mathrm{WZ}-\mathrm{CP}$ sample (see Fig. 1) indicating that either the $\mathrm{Au}^{\delta+}$ sites bear a greater positive charge or there is agglomeration of the gold particles after the high-temperature treatment with $\mathrm{NO}+\mathrm{O}_{2}$ mixture. It is likely that the species giving rise to the band at $2165 \mathrm{~cm}^{-1}$ could be $\mathrm{Au}^{+}$ adsorption sites dispersed on the surface of metallic gold particles as proposed in [36,37].

Spectrum (a) in Fig. 4 differs from the spectrum of adsorbed $\mathrm{CO}$ on the sample treated with $\mathrm{NO}+\mathrm{O}_{2}$ mixture at room temperature (Fig. 3, spectrum (c)). It seems that the oxidation of gold particles by the $\mathrm{NO}+\mathrm{O}_{2}$ mixture takes place at higher temperature $\left(300^{\circ} \mathrm{C}\right)$ and the absorption band at $2185 \mathrm{~cm}^{-1}$ detected during the $\mathrm{CO}$ adsorption on the sample treated with $\mathrm{NO}+\mathrm{O}_{2}$ mixture at room temperature (Fig. 3, spectra (b) and (c)) cannot be ascribed to $\mathrm{Au}^{+}-\mathrm{CO}$ species. This conclusion is supported also by the fact that the color of the $\mathrm{Au} / 18 \mathrm{WZ}-\mathrm{CP}$ sample after the pre-treatment with $\mathrm{NO}+\mathrm{O}_{2}$ mixture at room temperature remained the same as that of the activated sample, i.e. gray-black. However, the treatment with $\mathrm{NO}+\mathrm{O}_{2}$ mixture at $300^{\circ} \mathrm{C}$ causes changes in the color of the sample from gray-black to pale-violet.

Taking into account that the compounds adsorbed at room temperature on the $\mathrm{Au} / 18 \mathrm{WZ}-\mathrm{CP}$ sample are $\mathrm{CO}$ and $\mathrm{NO}_{x}$ species, it could be proposed that the strong band at $2185 \mathrm{~cm}^{-1}$ in Fig. 3 could be attributed to NCO species formed on metallic gold sites. According to the literature $[38,48,49]$ the $\mathrm{Au}-\mathrm{NCO}$ species give rise to absorption band at $2180-2190 \mathrm{~cm}^{-1}$. In order to verify this assumption we performed ${ }^{13} \mathrm{CO}$ adsorption on the sample treated with $\mathrm{NO}+\mathrm{O}_{2}$ mixture at room temperature (Fig. 5). The band at $2185 \mathrm{~cm}^{-1}$ is shifted down by $57 \mathrm{~cm}^{-1}$ and is positioned at $2128 \mathrm{~cm}^{-1}$ on ${ }^{13} \mathrm{C}$ substitution. The observed $\Delta v$ value is consistent with that reported by Celio et al. [50] for the isotopic shift detected on substituting ${ }^{13} \mathrm{C}$ for ${ }^{12} \mathrm{C}$ in NCO species adsorbed on $\mathrm{Cu}(100)$. From these results it can be concluded that the weak absorption at about $2130 \mathrm{~cm}^{-1}$ in Fig. 3 , spectrum (c) belongs to the ${ }^{13} \mathrm{CO}$ satellite of the band at $2185 \mathrm{~cm}^{-1}$.

The behavior of the absorption at $2185 \mathrm{~cm}^{-1}$ in the presence of water vapor can be used as additional evidence supporting the assignment of this feature to Au-NCO species. It is well known that the $\mathrm{NCO}$ species can react with water producing ammonia and $\mathrm{CO}_{2}$ through the formation of HNCO [11,51]. The species characterized

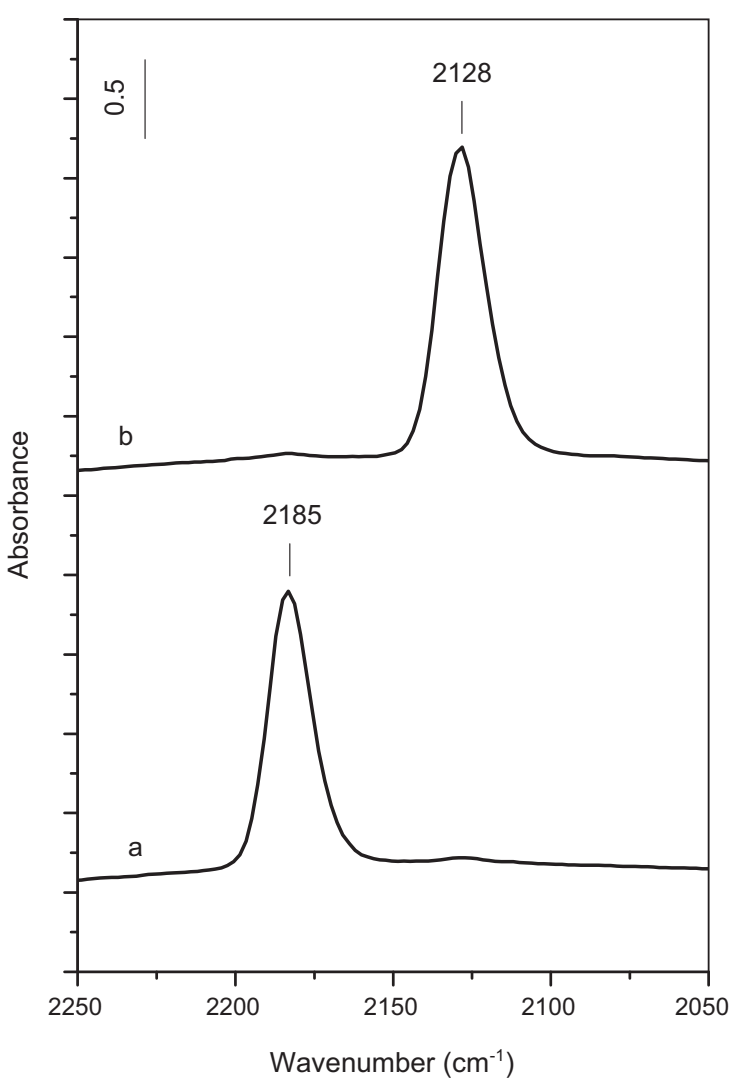

Fig. 5. FT-IR spectra of 10 Torr of $\mathrm{CO}(\mathrm{a})$ and $10 \mathrm{Torr}$ of ${ }^{13} \mathrm{CO}(\mathrm{b})$ adsorbed at room temperature on the Au/18WZ-CP sample.

by the absorption band at $2185 \mathrm{~cm}^{-1}$ are generated by adsorption of $\mathrm{CO}$ (10 Torr, for $10 \mathrm{~min}$ ) on the sample treated with $\mathrm{NO}+\mathrm{O}_{2}$ mixture at room temperature as described above and then the gaseous CO was evacuated for 15 min (Fig. 6A, spectrum (a)). The addition of 0.1 Torr of water vapor at room temperature causes significant decrease in the intensity of the band at $2185 \mathrm{~cm}^{-1}$ (Fig. 6A, spectrum (b)) and appearance of $\mathrm{CO}_{2}$ and $\mathrm{HNCO}\left(v_{\mathrm{as}}(\mathrm{NCO})\right.$ at $2266 \mathrm{~cm}^{-1}$ [51]) in the gas phase (Fig. 6B, spectrum (b)). The formation of the latter compounds confirms unambiguously the assignment of the band at $2185 \mathrm{~cm}^{-1}$ to $\mathrm{Au}-\mathrm{NCO}$ species. Increasing the temperature to $100{ }^{\circ} \mathrm{C}$ results in further decrease in the amount of isocyanates (Fig. 6A, spectrum (c)) and they disappear completely at $200^{\circ} \mathrm{C}$ (the spectrum is not shown). No ammonia was detected in the gas phase most likely because of its low concentration and/or adsorption on the catalyst surface. The sample spectra in the $\mathrm{NH}$ stretching region are noisy and are not representative. The bending modes of coordinated ammonia and $\mathrm{NH}_{4}{ }^{+}$ion fall in the region of stretching vibrations of the nitrates and if formed, they cannot be resolved. It should be noted that the adsorption of $\mathrm{CO}$ on the $\mathrm{NO}_{x}$-precoved $18 \mathrm{WZ}-\mathrm{CP}$ sample does not lead to the formation of NCO species which on oxides surfaces produce absorptions in the $2280-2200 \mathrm{~cm}^{-1}$ region $[38,46,48,49,52]$. The absence of NCO species coordinated to the support in the case of $\mathrm{Au} / 18 \mathrm{WZ}-\mathrm{CP}$ sample can be explained by unavailability of adsorption sites which are blocked by the nitrate species.

The Au-NCO species observed on the Au/18WZ-CP sample are characterized by high thermal stability and they are removed by dynamic evacuation at $350^{\circ} \mathrm{C}$ (Fig. 7).

\subsection{2. $\mathrm{NO}_{x}+\mathrm{CO}$ surface reaction}

The aim of this experiment is to investigate the possibility of CO to act as reducing agent toward the $\mathrm{NO}_{x}$ species adsorbed on the 


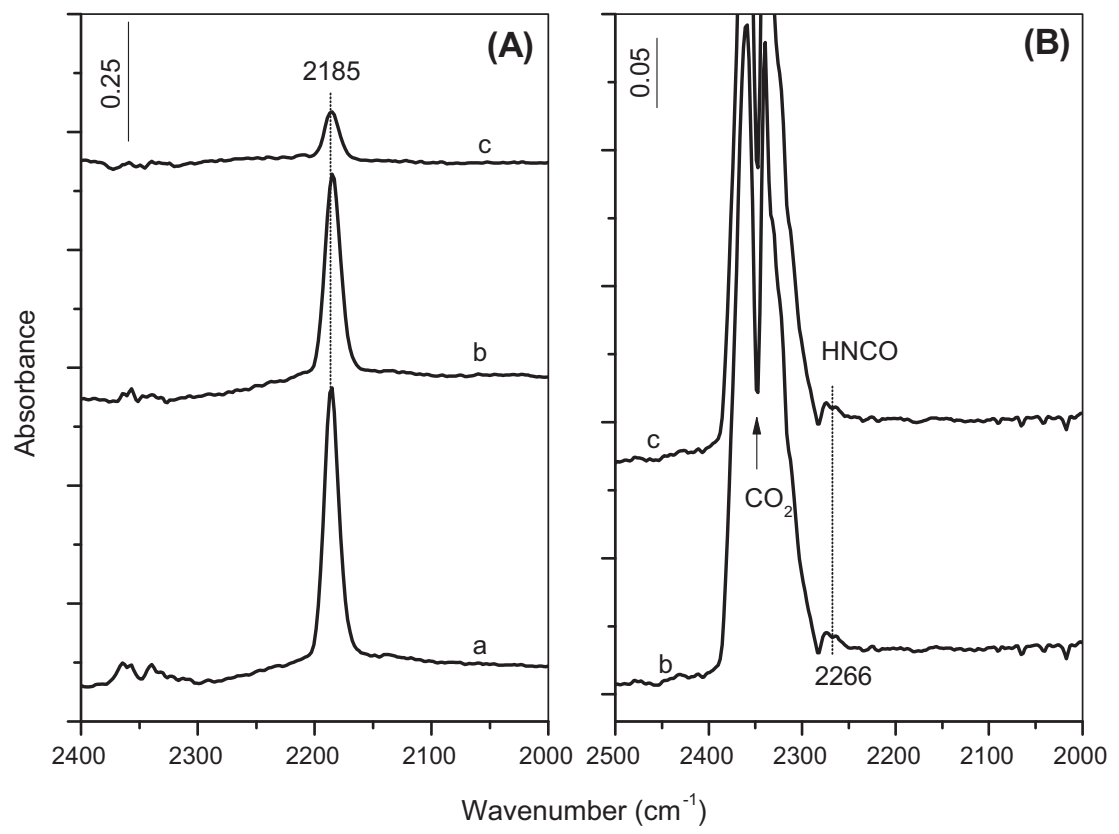

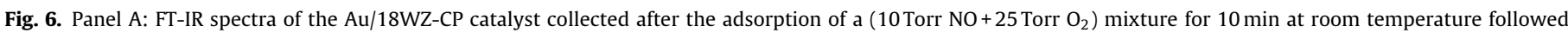

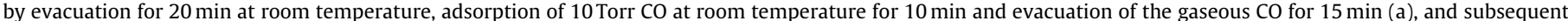
addition of 0.1 Torr of water vapor for $10 \mathrm{~min}$ at room temperature (b) and $100{ }^{\circ} \mathrm{C}$ (c). Panel B: Gas phase spectra corresponding to the sample spectra (b) and (c).

surface of the $\mathrm{Au} / 18 \mathrm{WZ}-\mathrm{CP}$ catalyst. Adsorbed nitrate species were created by adsorption of mixture of 10 Torr NO and 25 Torr $\mathrm{O}_{2}$ at RT for $10 \mathrm{~min}$ followed by evacuation for $20 \mathrm{~min}$ at RT (Fig. $8 \mathrm{~A}$, spectrum (a)). Then CO (10 Torr) was added (Fig. 8A, spectrum (b)) and

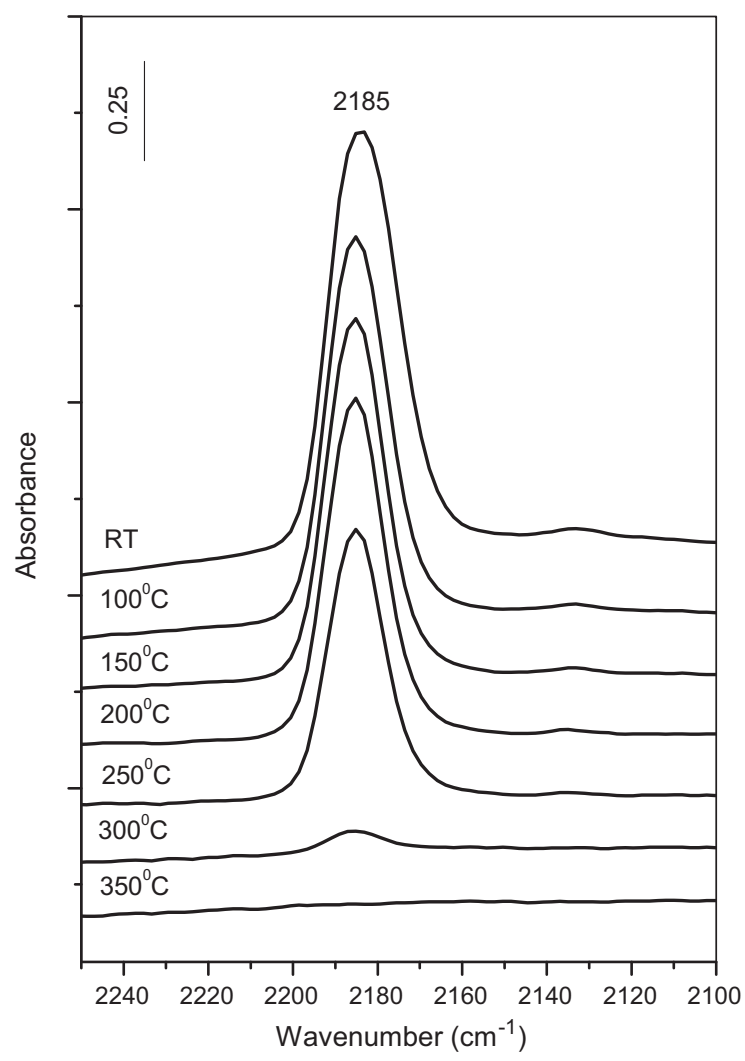

Fig. 7. FT-IR spectra of the Au/18WZ-CP catalyst collected after the adsorption of a $\left(10\right.$ Torr $\mathrm{NO}+25$ Torr $\left.\mathrm{O}_{2}\right)$ mixture for 10 min at room temperature followed by evacuation for $20 \mathrm{~min}$ at room temperature, adsorption of 10 Torr $\mathrm{CO}$ at room temperature for $10 \mathrm{~min}$ and evacuation of the gaseous $\mathrm{CO}$ for $15 \mathrm{~min}$ at various temperatures (RT = room temperature). the isolated IR cell was heated for $10 \mathrm{~min}$ at various temperatures. The sharp band at $2185 \mathrm{~cm}^{-1}$ assigned to Au-NCO species increases in intensity at $50^{\circ} \mathrm{C}$ (Fig. 8A, spectrum (c)) and disappears at $200^{\circ} \mathrm{C}$ (Fig. 8A, spectrum (f)) simultaneously with the $\mathrm{NO}_{2}$ observed in the gas phase (Fig. $8 \mathrm{~B}$, spectrum (f)). It can be concluded that the NCO species react with the $\mathrm{NO}_{2}$ leading to the formation of $\mathrm{CO}_{2}$ and $\mathrm{N}_{2}$. Some amounts of $\mathrm{N}_{2} \mathrm{O}$ and NO are detected as well. The fact that in the absence of $\mathrm{CO}$, the $\mathrm{NO}_{2}$ is present in the gas phase (Fig. 2) supports the assumption that the $\mathrm{NO}_{2}$ is reduced by $\mathrm{CO}$ through the intermediacy of Au-NCO species.

The spectra shown in Fig. 9 illustrate the reactivity of the Au-NCO species generated on the Au/18WZ-CP sample toward $\mathrm{NO}_{2}$. The absence of $\mathrm{CO}$ in the gas phase prevents the formation of additional Au-NCO species at $50^{\circ} \mathrm{C}$ (see Fig. 8A, spectrum (c)) and allows monitoring the onset temperature of the $\mathrm{NCO}+\mathrm{NO}_{2}$ reaction. The NCO species have been obtained by adsorption of 10 Torr of $\mathrm{CO}$ on the $\mathrm{NO}_{x}$-precovered $\mathrm{Au} / 18 \mathrm{WZ}-\mathrm{CP}$ sample followed by evacuation for $20 \mathrm{~min}$ at room temperature (Fig. 9, spectrum (a)). After the admission of 0.4 Torr of $\mathrm{NO}_{2}$ at room temperature (Fig. 9, spectrum (b)), the isolated IR cell was heated between 25 and $250{ }^{\circ} \mathrm{C}$ for $10 \mathrm{~min}$ at each temperature. The exposure of the sample to $\mathrm{NO}_{2}$ at room temperature (Fig. 9, spectrum (b)) causes strong decrease in the intensity of the band at $2185 \mathrm{~cm}^{-1}$ indicating that the $\mathrm{NCO}+\mathrm{NO}_{2}$ reaction takes place already at $25^{\circ} \mathrm{C}$. The surface concentration of the NCO species decreases rapidly with the temperature and they disappear at $250^{\circ} \mathrm{C}$ (Fig. 9, spectrum (g)). The gas phase spectra (not shown) contain $\mathrm{CO}_{2}$ and $\mathrm{NO}_{2}$ that has been taken in excess. As shown above, the Au-NCO species have high thermal stability and leave the surface upon dynamic evacuation at $350^{\circ} \mathrm{C}$ (Fig. 7). These results confirm the high reactivity of the isocyanates formed on the gold particles and suggest that the $\mathrm{Au} / 18 \mathrm{WZ}-\mathrm{CP}$ catalyst may have the potential for low-temperature reduction of $\mathrm{NO}_{x}$ with $\mathrm{CO}$ in the presence of oxygen.

In order to obtain information about the role of $\mathrm{WO}_{x}$ species in the $\mathrm{NO}_{x}+\mathrm{CO}$ surface reaction, we studied the interaction of $\mathrm{CO}$ with nitrate species pre-adsorbed on the $\mathrm{Au} / \mathrm{ZrO}_{2}$ catalyst. Also in this case, nitrate species (bands between 1700 and $1000 \mathrm{~cm}^{-1}$ ) were created by adsorption of mixture of 10 Torr NO and 25 Torr $\mathrm{O}_{2}$ at $\mathrm{RT}$ for $10 \mathrm{~min}$ followed by evacuation for $20 \mathrm{~min}$ at RT 

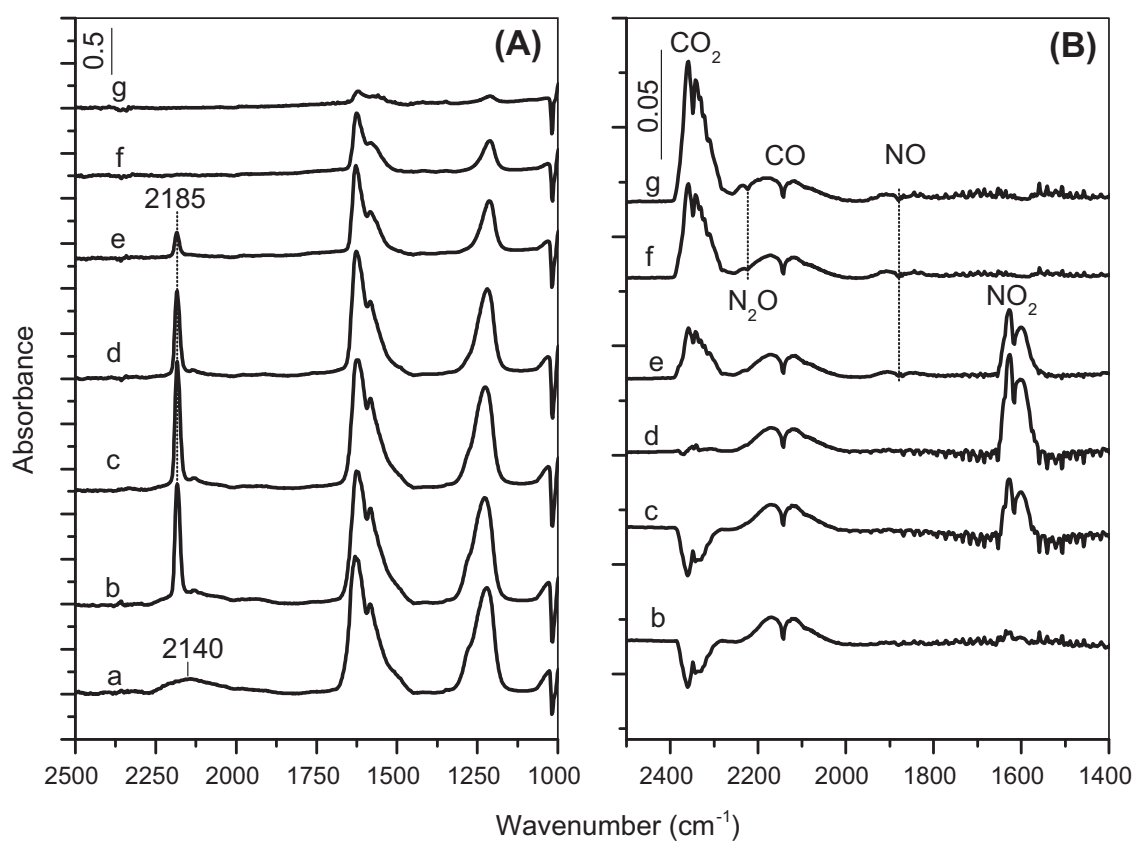

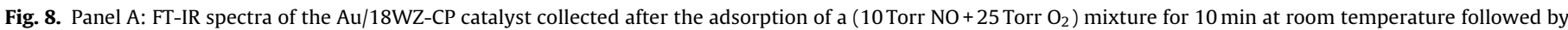

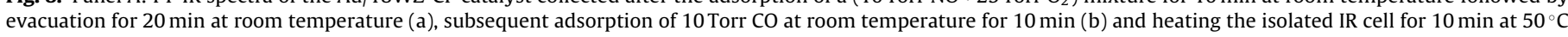
(c), $100^{\circ} \mathrm{C}(\mathrm{d}), 150^{\circ} \mathrm{C}(\mathrm{e}), 200^{\circ} \mathrm{C}$ (f) and $250^{\circ} \mathrm{C}$ (g). Panel B: Gas phase spectra collected at $25^{\circ} \mathrm{C}(\mathrm{b}), 50^{\circ} \mathrm{C}(\mathrm{c}), 100^{\circ} \mathrm{C}(\mathrm{d}), 150^{\circ} \mathrm{C}(\mathrm{e}), 200^{\circ} \mathrm{C}(\mathrm{f})$ and $250^{\circ} \mathrm{C}(\mathrm{g})$.

(Fig. 10A, spectrum (a)). After the addition of 10 Torr of $\mathrm{CO}$ at room temperature, the isolated IR cell was heated for $10 \mathrm{~min}$ at various temperatures. As with the Au/18WZ-CP sample, the sharp band at $2184 \mathrm{~cm}^{-1}$ is characteristic of NCO species adsorbed on Au. The

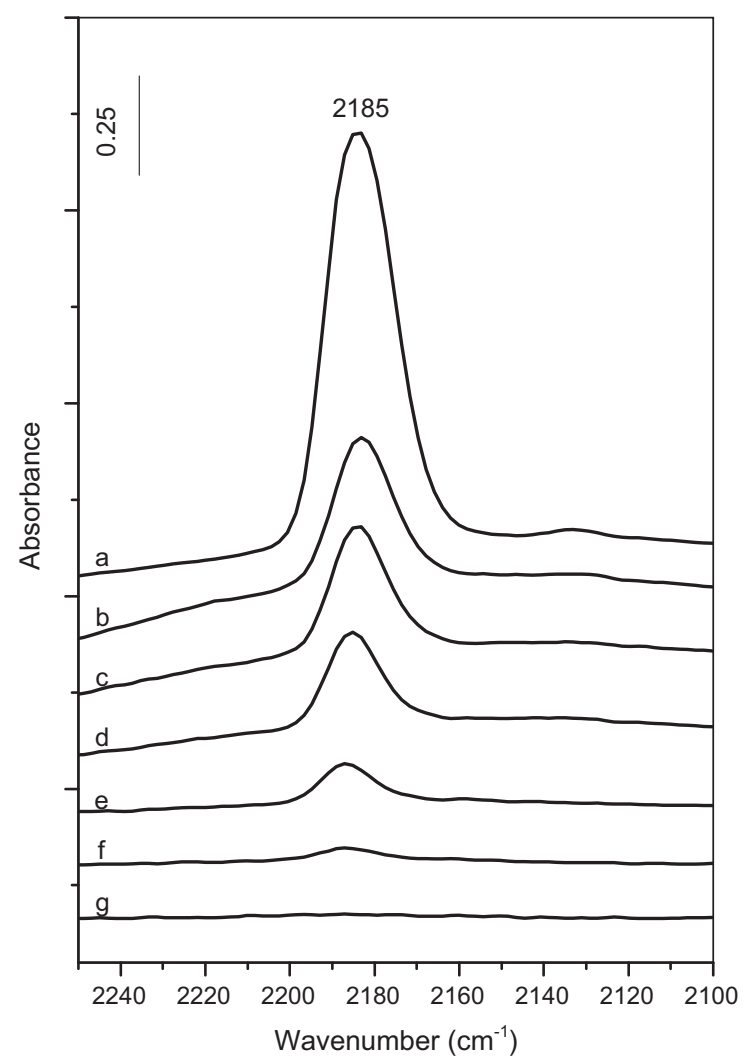

Fig. 9. FT-IR spectra of the Au/18WZ-CP catalyst collected after the generation of the $\mathrm{Au}-\mathrm{NCO}$ species (a) (for the conditions see Fig. 7, spectrum (RT)) and subsequent addition of 0.4 Torr of $\mathrm{NO}_{2}$ for $10 \mathrm{~min}$ at $25^{\circ} \mathrm{C}$ (b), $50{ }^{\circ} \mathrm{C}$ (c), $100^{\circ} \mathrm{C}$ (d), $150^{\circ} \mathrm{C}$ (e), $200^{\circ} \mathrm{C}(\mathrm{f})$ and $250^{\circ} \mathrm{C}(\mathrm{g})$. comparison of the spectra shown in Figs. 8 and 10 leads to the conclusion that the $\mathrm{WO}_{x}$-containing catalyst should have higher activity because the adsorbed $\mathrm{NCO}$ species and $\mathrm{NO}_{2}$ disappear at $200{ }^{\circ} \mathrm{C}$ whereas in the case of $\mathrm{Au} / \mathrm{ZrO}_{2}$ sample they are present at this temperature. Despite of the higher concentration of surface nitrates on the $\mathrm{Au} / \mathrm{ZrO}_{2}$ sample, the amount of evolved $\mathrm{NO}_{2}$ is lower. This suggests that the surface tungstates lower the stability of the nitrate ions. In addition, the weak absorptions at 1450 and $1420 \mathrm{~cm}^{-1}$ observed in the spectrum of $\mathrm{Au} / \mathrm{ZrO}_{2}$ detected at $250^{\circ} \mathrm{C}$ indicate the formation of stable polydentate carbonates $[53,54]$ which may have negative effect on the catalytic activity. No such species are found in the case of the Au/18WZ-CP sample.

Finally, it should be noted that the Au-free 18WZ-CP sample does not catalyze the interaction between adsorbed $\mathrm{NO}_{x}$ species and $\mathrm{CO}$ : the evolved $\mathrm{NO}_{2}$ is present in the gas phase between 25 and $350{ }^{\circ} \mathrm{C}$ (the data are not shown).

\subsubsection{Interaction of a (10 Torr $N O+14$ Torr $\mathrm{CO})$ mixture with $\mathrm{Au} / 18 \mathrm{WZ}-\mathrm{CP}$}

The aim of this experiment is to show the role of $\mathrm{NO}+\mathrm{O}_{2}$, respectively $\mathrm{NO}_{2}$, for the formation of $\mathrm{Au}-\mathrm{NCO}$ species. The spectra (Fig. 11) are collected in the presence of $\mathrm{NO}+\mathrm{CO}$ reaction mixture at various temperatures. The band at $2230 \mathrm{~cm}^{-1}$ observed in the spectrum taken at room temperature (Fig. 11A, spectrum (a)) is typical of adsorbed $\mathrm{N}_{2} \mathrm{O}$ which is present as impurity in the gaseous $\mathrm{NO}$ (Fig. 11B). The absorption at $2198 \mathrm{~cm}^{-1}$ corresponds to $\mathrm{Zr}^{4+}-\mathrm{CO}$ whereas the signal at $2118 \mathrm{~cm}^{-1}$ is assigned to $\mathrm{Au}^{0}-\mathrm{CO}$ species (Fig. 11A). The spectrum recorded at RT contains absorption bands which are attributed to bidentate $\mathrm{HCO}_{3}{ }^{-}\left(1606\right.$ and $\left.1222 \mathrm{~cm}^{-1}\right)$, bidentate ( 1555 and $1305 \mathrm{~cm}^{-1}$ ) and polydentate carbonates (1456 and $1420 \mathrm{~cm}^{-1}$ ) [53,54]. The assignment of the absorptions in the $1700-1000 \mathrm{~cm}^{-1}$ region to carbonate species is confirmed by the FT-IR spectra of adsorbed CO taken in the $25-250{ }^{\circ} \mathrm{C}$ temperature range. The data are not shown for the sake of brevity. The intensities of the bands at 2230, 2198 and $2118 \mathrm{~cm}^{-1}$ decrease with the temperature and these absorptions are no longer present in the spectrum taken at $150^{\circ} \mathrm{C}$ (Fig. $11 \mathrm{~A}$, spectrum (d)). Only $\mathrm{Zr}^{4+}-\mathrm{NO}$ nitrosyl $\left(1937 \mathrm{~cm}^{-1}[55]\right)$ and $\mathrm{NO}^{-}\left(1178 \mathrm{~cm}^{-1}[47,55]\right)$ ion are 


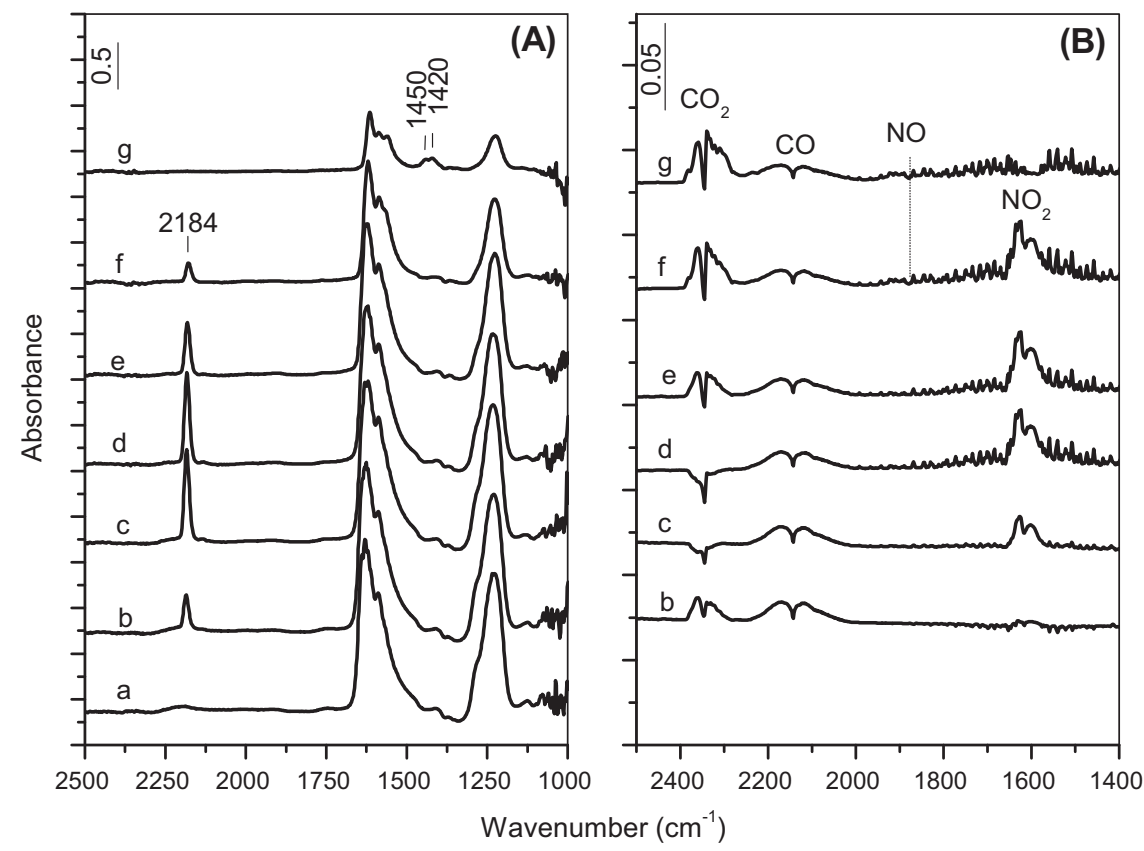

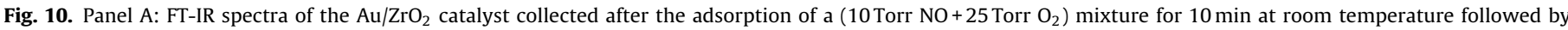

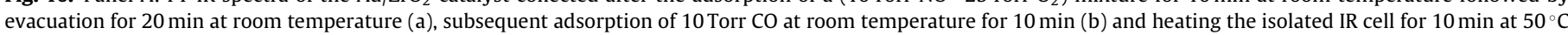
(c), $100^{\circ} \mathrm{C}(\mathrm{d}), 150^{\circ} \mathrm{C}(\mathrm{e}), 200^{\circ} \mathrm{C}$ (f) and $250^{\circ} \mathrm{C}$ (g). Panel B: Gas phase spectra collected at $25^{\circ} \mathrm{C}(\mathrm{b}), 50^{\circ} \mathrm{C}(\mathrm{c}), 100^{\circ} \mathrm{C}(\mathrm{d}), 150^{\circ} \mathrm{C}(\mathrm{e}), 200^{\circ} \mathrm{C}(\mathrm{f})$ and $250{ }^{\circ} \mathrm{C}(\mathrm{g})$.

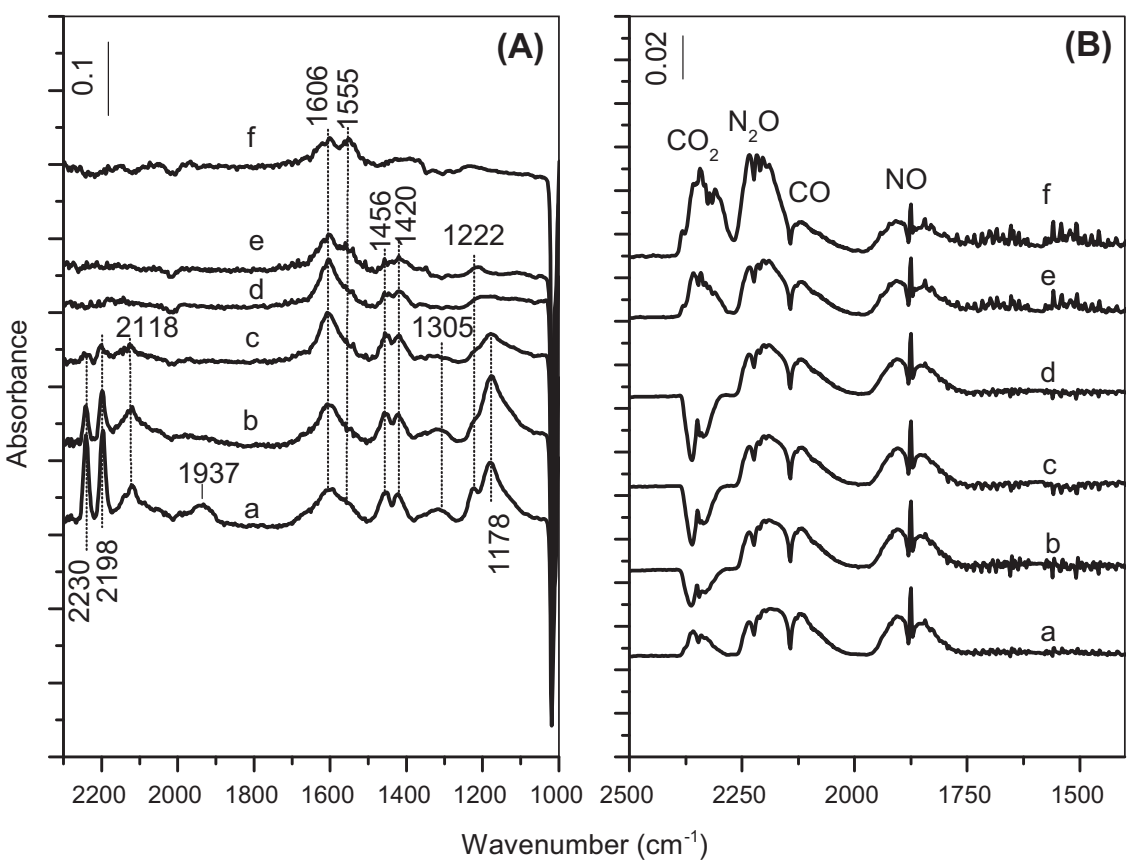

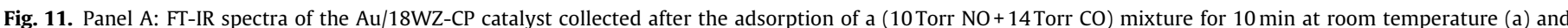

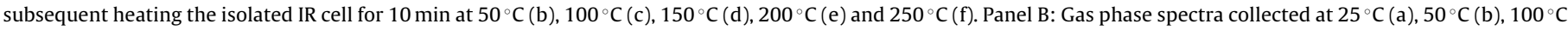
(c), $150^{\circ} \mathrm{C}(\mathrm{d}), 200^{\circ} \mathrm{C}(\mathrm{e})$ and $250^{\circ} \mathrm{C}(\mathrm{f})$.

identified as $\mathrm{NO}_{x}$ species adsorbed at room temperature. No surface nitrates and Au-NCO species are formed even at higher temperatures. This fact indicates that the nitrate species or activated $\mathrm{NO}_{2}$ are essential for the formation of Au-NCO species and that the oxidation of NO by oxygen is an important step. The gas phase spectra (Fig. 11B) show that the amount of $\mathrm{N}_{2} \mathrm{O}$ increases with the temperature being the highest at $250^{\circ} \mathrm{C}$ (spectrum (f)) when the $\mathrm{NO}^{-}$ species are removed completely from the surface. The $\mathrm{CO}_{2}$ detected in the gas phase at $200^{\circ} \mathrm{C}$ (Fig. $11 \mathrm{~B}$, spectrum (e)) most likely appears as a result of decomposition of the surface carbonates.

\section{Conclusions}

Gold catalysts prepared by cationic adsorption of aqueous solution of $\left[\mathrm{Au}(\mathrm{en})_{2}\right] \mathrm{Cl}_{3}$ complex on zirconia and tungstated zirconia have been investigated by in situ FT-IR spectroscopy. The adsorption of CO shows the presence of positively charged (or large gold clusters) and neutral gold particles on both supports. Detailed FTIR investigation of the interaction between $\mathrm{CO}$ and $\mathrm{NO}_{x}$ species pre-adsorbed on $\mathrm{Au} / \mathrm{ZrO}_{2}$ and $\mathrm{Au} / \mathrm{ZrO}_{2}-\mathrm{WO}_{x}$ samples reveal the formation of surface isocyanates attached to the gold particles. 
The generation of Au-NCO species occurs at low temperature $\left(25-50^{\circ} \mathrm{C}\right)$. The gold isocyanates display high thermal stability. However, they react readily with $\mathrm{NO}_{2}$ at room temperature. During the ad $-\mathrm{NO}_{x}+\mathrm{CO}$ reaction over the $\mathrm{Au} / \mathrm{ZrO}_{2}-\mathrm{WO}_{x}$ sample, the gold isocyanates disappear at $200{ }^{\circ} \mathrm{C}$ simultaneously with the $\mathrm{NO}_{2}$ that is generated in the gas phase by decomposition of the surface nitrates. This process on the $\mathrm{Au} / \mathrm{ZrO}_{2}$ catalyst takes place at higher temperature $\left(250^{\circ} \mathrm{C}\right)$. It is concluded that the incorporation of $\mathrm{W}$ to zirconia decreases the stability of the adsorbed nitrates. The Aufree tungstated zirconia does not catalyze the interaction between adsorbed nitrates and $\mathrm{CO}$ : the evolved $\mathrm{NO}_{2}$ is present in the gas phase between 25 and $350^{\circ} \mathrm{C}$.

No formation of surface nitrates and $\mathrm{Au}-\mathrm{NCO}$ species is detected during the $\mathrm{NO}+\mathrm{CO}$ adsorption on $\mathrm{Au} / \mathrm{ZrO}_{2}-\mathrm{WO}_{x}$ catalyst in the $25-250^{\circ} \mathrm{C}$ temperature range. This result implies that the nitrate species or adsorbed $\mathrm{NO}_{2}$ are essential for the generation of gold isocyanates and the oxidation of $\mathrm{NO}$ by oxygen is an important step. In the absence of $\mathrm{CO}$, gaseous $\mathrm{NO}_{2}$ over both Au-containing catalysts is observed in the $25-350{ }^{\circ} \mathrm{C}$ temperature range. This fact supports the conclusion that $\mathrm{NO}_{2}$ is reduced by $\mathrm{CO}$ with the intermediacy of Au-NCO species leading to the formation of $\mathrm{N}_{2}$ and $\mathrm{CO}_{2}$. The results of in situ FT-IR spectroscopic investigation presume that Au supported on tungstated zirconia might be potential candidate for the development of low-temperature catalyst for the selective reduction of $\mathrm{NO}_{x}$ with $\mathrm{CO}$.

\section{Acknowledgments}

This work was financially supported by the Scientific and Technological Research Council of Turkey (Project TBAG-109T854) and Bilkent University. The financial support of NATO grant ESP.CLG. No. 984160 is greatly appreciated.

\section{References}

[1] M. Iwamoto, in: A. Corma, F.V. Melo, S. Mendioroz, J.L.G. Fierro (Eds.), Stud. Surf. Sci. Catal., vol. 130, 2000, pp. 23-47.

[2] R. Burch, J.P. Breen, F.C. Meunier, Applied Catalysis B 39 (2002) 283-303.

[3] R. Burch, Catalysis Reviews: Science and Engineering 46 (2004) 271-334.

[4] M.C. Kung, H.H. Kung, Topics in Catalysis 28 (2004) 105-110.

[5] M. Haneda, T. Yoshinari, K. Sato, Y. Kintaichi, H. Hamada, Chemical Communications (2003) 2814-2815.

[6] M. Shimokawabe, N. Umeda, Chemistry Letters 33 (2004) 534-535.

[7] A. Takahashi, I. Nakamura, M. Haneda, T. Fujitani, H. Hamada, Catalysis Letters 112 (2006) 133-138.

[8] H. Inomata, M. Shimokawabe, M. Arai, Applied Catalysis A 332 (2007) 146-152.

[9] M. Haneda, H. Hamada, Chemistry Letters 37 (2008) 830-831.

[10] T. Nanba, S. Shinohara, J. Uchisawa, S. Masukawa, A. Ohi, A. Obuchi, Chemistry Letters 53 (2006) 450-451.

[11] T. Nanba, K.-I Wada, S. Masukawa, J. Uchisawa, A. Obuchi, Applied Catalysis A 380 (2010) 66-71.

[12] M. Haruta, N. Yamada, T. Kobayashi, S. Iijima, Journal of Catalysis 115 (1989) 301-309.

[13] M. Haruta, M. Date, Applied Catalysis A 222 (2001) 427-437.

[14] M. Kantcheva, M. Milanova, I. Avramova, S. Mametsheripov, Catalysis Today (2012), http://dx.doi.org/10.1016/j.cattod.2012.02.027, in press.

[15] J.G. Santiesteban, J.V. Vartuli, S. Han, R.D. Bastian, C.D. Chang, Journal of Catalysis 168 (1997) 431-441.
[16] B.P. Block, J.C. Bailar Jr., Journal of the American Chemical Society 73 (1951) $4722-4725$.

[17] R.A. Boyse, E. Ko, Journal of Catalysis 171 (1997) 191-207.

[18] M. Scheithauer, R.K. Grasselli, H. Knozinger, Langmuir 14 (1998) 3019-3029.

[19] D.G. Barton, M. Shtein, R.D. Wilson, S.T. Soled, E. Iglesia, Journal of Physica Chemistry B 103 (1999) 630-640.

[20] E.I. Ross-Medgaarden, W.V. Knowles, T. Kim, M.S. Wong, W. Zhou, C.J. Kiely, I.E. Wachs, Journal of Catalysis 256 (2008) 108-125.

[21] M. Kantcheva, C. Koz, Journal of Materials Science 42 (2007) 6074-6086.

[22] R. Zanella, A. Sandoval, P. Santiago, V.A. Basink, J.M. Saniger, Journal of Physical Chemistry B 110 (2006) 8559-8565.

[23] F. Boccuzzi, G. Cerrato, F. Pinna, G. Strukul, Journal of Physical Chemistry B 102 (1998) 5733-5736.

[24] R. Kydd, J. Scott, W.Y. Teoh, K. Chiang, R. Amal, Langmiur 26 (2010) 2099-2106.

[25] J.-D. Grunwald, M. Maciejewski, O.S. Becker, P.F. Fabrizioli, A. Baiker, Journal of Catalysis 186 (1999) 458-469.

[26] M. Maciejewski, P. Fabrizioli, J.-D. Grunwald, O.S. Becker, A. Baiker, Physica Chemistry Chemical Physics 3 (2001) 3846-3855.

[27] M. Manzoli, A. Chiorino, F. Boccuzzi, Surface Science 532-535 (2003) 377-382.

[28] F. Boccuzzi, A. Chiorino, Journal of Physical Chemistry B 104 (2000) 5414-5416.

[29] F. Vindigni, M. Manzoli, A. Chiorino, F. Boccuzzi, Gold Bulletin 42 (2009) 106-112.

[30] D. Guillemot, V.Y. Borovkov, V.B. Kazansky, M. Polisset-Thfoin, J. Fraissard, Journal of the Chemical Society, Faraday Transactions 93 (1997) 3587-3591.

[31] S. Minico, S. Scire, C. Crisafulli, A.M. Visco, S. Galvagno, Catalysis Letters 47 (1997) 273-276.

[32] M. Li, Z. Wu, Z. Ma, V. Schwartz, D.R. Mullins, S. Dai, S.H. Overbury, Journal of Catalysis 266 (2009) 98-105.

[33] M.A. Dekkers, M.J. Lippits, B.N. Nieuwenhuys, Catalysis Letters 56 (1998) 195-197.

[34] K.I. Hadjiivanov, G.N. Vayssilov, Advances in Catalysis 47 (2002) 307-511.

[35] T. Venkov, K. Fajerwerg, L. Delannoy, H. Klimev, K. Hadjiivanov, C. Louis, Applied Catalysis A 301 (2006) 106-114.

[36] M.A. Centeno, K. Hadjiivanov, T. Venkov, H. Klimev, J.A. Odriozola, Journal of Molecular Catalysis A: Chemical 252 (2006) 142-149.

[37] M. Mihaylov, B.C. Gates, J.F. Fierro-Gonzales, K. Hadjiivanov, H. Knözinger, Journal of Physical Chemistry C 111 (2007) 2548-2556.

[38] M. Kantcheva, O. Samarskaya, L. Ilieva, G. Pantaleo, A.M. Venezia, D. Andreeva, Applied Catalysis B 88 (2009) 113-126.

[39] D. Andreeva, M. Kantcheva, I. Ivanov, L. Ilieva, J.W. Sobczak, W. Lisowski, Catalysis Today 158 (2010) 69-77.

[40] R. Meyer, C. Lemire, S.K. Shaikhutdinov, H.-F. Freund, Gold Bulletin 37 (2004) $72-124$.

[41] K. Musialska, E. Finocchio, I. Sobczak, G. Busca, R. Wojcieszak, E. Gaigneaux, M Ziolek, Applied Catalysis A 384 (2010) 70-77.

[42] V.A. Sadykov, V.V. Lunin, V.A. Matyshak, E.A. Paukshtis, A.Y. Rozovskii, N.N. Bulgakov, J.R.H. Ross, Kinetics and Catalysis (Eng.) 44 (2003) 379-400.

[43] M. Kantcheva, A.S. Vakkasoglu, Journal of Catalysis 223 (2004) 364-371

[44] M. Kantcheva, I. Cayirtepe, Catalysis Letters 115 (2007) 148-162.

[45] B. Tsyntsarski, V. Avreyska, H. Kolev, T. Marinova, D. Klissurski, K. Hadjiivanov, Journal of Molecular Catalysis A: Chemical 193 (2003) 139-149.

[46] T. Weingand, S. Kuba, K. Hadjiivanov, H. Knözinger, Journal of Catalysis 209 (2002) 539-546.

[47] M. Kantcheva, I. Cayirtepe, Journal of Molecular Catalysis A: Chemical 247 (2006) 86-98.

[48] F. Solymosi, T. Bansagi, T. Suli Zakar, Physical Chemistry Chemical Physics 5 (2003) 4724-4730.

[49] F. Solymosi, T. Bansagi, T. Suli Zakar, Catalysis Letters 87 (2003) 7-10.

[50] H. Celio, K. Mudalige, P. Mills, M. Trenary, Surface Science 394 (1997) L168-L173.

[51] G. Piazzesi, O. Kröcher, M. Elsener, A. Wokaun, Applied Catalysis B 65 (2006) 55-61.

[52] F. Solymosi, T. Bánsági, Journal of Physical Chemistry 83 (1979) 552-553.

[53] B. Bachiller-Baeza, I. Rodriguez-Ramos, A. Guerrero-Ruiz, Langmuir 14 (1998) 3556-3564.

[54] K. Pokrovski, K.T. Jung, A.T. Bell, Langmuir 17 (2001) 4297-4303.

[55] M. Kantcheva, E.Z. Ciftlikli, Journal of Physical Chemistry B 106 (2002) 3941-3949. 